\title{
Konsep Diri Lansia di Panti Jompo
}

\section{Yiyit Hentika}

Universitas Negeri Padang

*) Correspondence regarding this article should be addressed to: Author address e-mail: Yiyit22@gmail.com

\begin{abstract}
When someone getting old, he/she will get physical changing and physical decreasing which is influencing self-concept decreasing. From the result of introduction study in Tresna Werdha Sabai Nan Aluih Sicincin, the researchers get data as 110 oldsters male and female. Based on the interview to these three elders that has been nursed in this dwelling, one elder says happy although living far away from the family and the brother feels grateful, 2 elders say that they feel sad and yearning of their family. The elders describe their selves that they are old, sick often, and have low self esteem, shy, and feeling inferior. Living in the dwelling is like being thrown away and do not have any interactions anymore
\end{abstract}

Keywords: self concept, Older, Nursing home

Article History: Received on 07/07/2019; Revised on 08/08/2019; Accepted on 18/08/2019; Published Online: $31 / 08 / 2019$.

This is an open access article distributed under the Creative Commons Attribution License, which permits unrestricted use,
distribution, and reproduction in any medium, provided the original work is properly cited. (C)2019 by author.

\section{PENDAHULUAN}

Pada usia lanjut orang yang lanjut usia akan mengalami berbagai macam masalah termasuk dengan masalah konsep diri. WHO menggungkapkan bahwa penyebab timbulnya permasalahan pada lanjut usia adalah masalah fisik, psikososial, spiritual, mental, stress, ekonomi dan penurunnan fungsi kognitif dan psikomotor, hal ini akan mempengarui konsep diri. Konsep diri yang menurun akan mempengarui pemikiran pada lanjut usia dalam menilai dirinya baik itu penilaian diri secara positif maupun negatif. Pada lansia yang tinggal dipanti memberikan stres tersendiri yang akan mempengarui ideal diri, citra diri, harga diri, peran dan penampilanya serta gambaran diri, gambaran diri yang negatif menggagap dirinya sudah tua, berarti sakit-sakitan, lemah, membosankan, buruk rupa, bahkan julukkan negatif lainnya, anggapan semacam itu maka, akan mempengarui penurunan konsep diri pada lansia, sehingga lansia lebih cenderung menarik diri dan jarang berinteraksi dengan lingkungan sekitar ( Rahayu, Hiswani, Rasmalah, 2003).

Menurut Nugroho (2008), lanjut usia akan mengalami banyak perubahan dan penurunan fungsi fisik dan psikologis hal ini akan menimbulkan berbagai masalah pada lanjut usia yang akan mempengarui lanjut usia dalam menilai dirinya sendiri yang disebut konsep diri. 
Dampak dari menurunnya konsep diri pada lanjut usia menyebabkan bergesernya peran sosial dalam berinteraksi sosial di masyarakat maupun dikeluarga. Hal ini didukung oleh sikap lansia yang cenderung egois dan enggan mendengarkan pendapat orang lain, sehingga mengakibatkan lansia terasing secara sosial dan akhirnya merasa terisolir dan merasa tidak berguna lagi karena tidak ada penyaluran emosional dari bersosialisasi. Keadaan ini mengakibatkan interaksi sosial menurun baik secara kualitas maupun kuantitas karena peran lansia yang digantikan kaum muda, dimana keadaan ini terjadi sepanjang hidup dan tidak dapat dihindari (Standley \& Beare, 2007).

Seiring dengan bertambahnya usia, lansia mengalami perubahan dalam hidup mereka misalnya, hilangnya pekerjaan, pensiun, berubahnya peran sosial, merasa ditinggalkan dan jauh dari anak cucu, kehilangan pasangan suami atau istri, jika penyesuaikan diri pada lansia dalam menghadapi perubahan dalam kehidupannya lambat dan tidak mampu menyesuaikan diri, hal ini akan menimbulkan kondisi stress dan akan semakin bertambahnya beban mental pada lansia, kondisi ini menyebabkan lansia jarang bersosialisasi dan berinteraksi. Keadaan ini cenderung berpotensi menimbulkan masalah kesehatan secara umum (fisik) maupun kesehatan jiwa secara khusus (Nugroho, 2008).

Selain itu lanjut usia mengakui dan menyadari bahwa dirinya mengalami perubahan pada kondisi fisknya misalnya, kulit yang memulai keriput, rambut yang ubanan, tidak bisa melakukan aktivitas seperti masa muda. Hal tersebut secara tidak langsung akan berpengaruh pada konsep diri lansia, khususnya pada gambaran dirinya yang selalu mengagap dirinya rendah. Didalam perubahan peran yang ada pada lansia juga sangat mempengarui konsep dirinya seperti menarik diri, jarang berinteraksi dengan orang disekitar, menganggap dirinya rendah, menaggap dirinya sudah tidak berguna.

\section{PEMBAHASAN}

\section{Konsep diri}

Konsep diri adalah pandangan seseorang tentang dirinya sendiri yang menyangkut apa yang ia ketahui dan rasakan tentang perilakunya, isi pikiran dan perasaannya, serta bagaimana perilakunya tersebut berpengaruh terhadap orang lain. (H. Jaali, 2008:129130). Di sini konsep diri yang dimaksud adalah bayangan seseorang tentang keadaan dirinya sendiri pada saat ini bukanlah bayangan ideal dari dirinya sendiri sebagaimana yang diharapkan atau yang disukai oleh individu bersangkutan. Konsep diri berkembang dari pengalaman seseorang tentang berbagai hal mengenai dirinya sejak ia kecil, terutama yang berkaitan dengan perilaku orang lain terhadap dirinya.

Konsep diri seseorang mula-mula terbentuk dari perasaan apakah ia diterima dan diinginkan kehadirannya oleh keluarganya. Melalui perlakuan yang berulang-ulang dan setelah menghadapi sikap-sikap tertentu dari ayah-ibu-kakak dan adik ataupun orang lain di lingkup kehidupannya, akan berkembanglah konsep diri seseorang. Konsep diri ini yang pada mulanya berasal dari perasaan dihargai atau tidak dihargai. Perasaan inilah yang menjadi landasan dari pandangan, penilaian, atau bayangan seseorang mengenai dirinya sendiri yang keseluruhannya disebut konsep diri. Dalam teori Psikoanalisis, 
proses perkembangan konsep diri disebut proses pembentukan ego (the process of ego formation). Menurut aliran ini, ego yang sehat adalah ego yang dapat mengontrol dan mengarahkan kebutuhan primitive (dorongan libido) supaya setara dengan dorongan dari super ego serta tuntutan lingkungan.

Untuk mengembangkan ego atau diri (self) yang sehat adalah dengan memeberikan kasih sayang yang cukup dan dengan cara orang tua menunjukkan sikap menerima anaknya dengan segala kelebihan dan kekurangnnya, terutama pada tahun-tahun pertama dari perkembangannya.

Dalam kaitan ini, konsep diri menurut Erikson berkembang melalui lima tahap, yaitu sebagai berikut:

1. Perkembangan dari sense of trust vs sense of mistrust, pada anak usia 11/2-2 tahun. Melalui hubungan dengan orang tuanya anak akan mendapat kesan dasar apakah orang tuanya merupakan pihak yang dapat dipercaya atau tidak. Apabila ia yakin dan merasa bahwa orang tuanya dapat member perlindungan dan arasa aman bagi dirinya pada diri anak akan timbul rasa percaya diri terhadap orang dewasa, yang nantinya akan berkembang menjadi berbagai perasaan yang sifatnya positif.

2. Perkembangan dari sense of anatomy ws shame and doubt, paad anak usia 2-4 tahun. Yang terutama berkembang pesat pada usia ini adalah kemampuan motorik dan berbahasa, yang keduanya memungkinkan anak menjadi lebih mandiri (autonomy). Apabila anak diberi kesempatan untuk melakukan segala sesuatu menurut kemampuannya, sekalipun kemampuannya terbatas, tanpa terlalu banyak ditolong apalagi dicela, maka kemandirian akan terbentuk. Sebaliknya ia sering merasa malu dan ragu-ragu bila tidak memperoleh kesempatan membuktikan kemampuannya.

3. Perkembangan dari sense of initiative vs sense of guilt, pada anak usia 4-7 tahun. Anak usia 4-7 tahun selalu menunjukkan perasaan ingin tahu, begitu juga sikap ingin menjelajah, mencoba-coba. Apabila anak sering mendapat hukuman karena perbuatan tertentu yang didorong oleh perasaan ingin tahu dan menjelajah tadi, keberaniannya untuk mengambil insiatif akan berkurang. Yang nantinya berkembang justru adalah perasaan takut-takut dan perasaan bersalah.

4. Perkembangan dari sense of industry vs inferiority, pada usia 7-11 atau 12 tahun. Inilah masa anak ingin membuktikan keberhasilan dari usahanya. Mereka berkompetisi dan berusah untuk bisa mununjukkan prestasi. Kegagalan yang berulang-ulang dapat mematahkan semangat dan menimbulkan perasaan rendah diri.

5. Perkembangan dari sense of identity diffusion, pada remaja. Remaja biasanya sangat besar minatnya terhadap diri sendiri. Biasanya mereka ingin memperoleh jawaban tentang siapa dan bagimana dia. Dalam menemukan jawabannya mereka akan mengumpulkan berbagai informasi yang berhubungan dengan konsep dirinya pada masa lalu. Apabila informasi kenyataan, perasaan, dan pengalaman yang dimilki mengenai diri sendiri tidak dapat diintegrasi hingga membentuk suatu konsep diri yang utuh, remaja akan terus-menerus bimbang dan tidak mengerti tentang dirinya sendiri. 
Menurut Stuart dan Sundeen (fransisca dan arum) bahwa konsep diri adalah semua ide pikiran kepercyaan dan pendirian yang mempengaruhi individu dalam berhubungan dengan orang lain.Sedangkan menurut Beck, William da Rawlin (1994) konsep diri adalah cara individu memandang dirinnya secara utuh.

Burn juga merumuskan bahwa konsep diri diartikan sebagai segala keyakinan seseorang pada diri sendiri. Konsep diri akan menentukan siapa seseorang itu dalam kenyataannya, siapa seseorang itu menurut pikirannya, dan akan menentukan bisa menjadi apa seseorang itu menurut pikirannya sendiri. Dalam definisi lain, konsep diri merupakan kumpulan pengetahuan, ide, sikap, dan kepercayaan tentang apa yang terdapat dalam diri sendiri. Eggen dan Kauchak dalam (I Nyoman dan Olga:2014) berpendapat bahwa konsep diri adalah penilaian kognitif berkenaan dengan fisik, sosial, dan kompetensi akademik.

Menurut (Nyoman Dan Olga : 2014)Konsep diri dirumuskan sebagai sesuatu yang terorganisasikan secara utuh, dan bersifat konsisten; secara konseptual tersusun dari persepsi yang utuh yang menunjuk pada pemaknaan "I or Me" yang meliputi berbagai aspek dalam kehidupan. Berpijak pada prinsip Gestalt, maka tanggapan dan pemahaman seseorang tergantung pada medan pengamatan dan pengalaman yang utuh dan didasarkan pada persepsi yang disadari dan nila-nilai "I and me". Konsep diri adalah sebuah citra pada diri sendiri, secara khusus berkenaan dengan kesadaran sebagai pribadi (what "I" am) dan kesadaran tentang fungsi pribadi (what "I" can do).

\section{Faktor-faktor pembentuk konsep diri}

Faktor yang membentuk konsep diri yaitu keluarga, perannya apa, pengalaman apa yang pernah dialui, situasi lingkungan sekitar. Keluarga merupakan organisasi yang pertama dan utama dalam pelaksanaan interaksi West dan Tuner, (Fransisca dan Arum Yudaryati). Faktor-faktor yang mempengaruhi konsep diri yaitu ; Pengalaman interpersonal, kompetensi dalam pekerjaan yang dimilki, aktualisasi diri, implementasi dan realisasi dari potensi yang benar- benar dan seharusnya.Faktor lain yang memepengaruhi konsep diri yaitu ; Significant Other (orang yang terpenting atau terdekat) dan Self Perception (persepsi diri sendiri)

Pengertian Lansia

Menjadi tua memang bukan pilihan melainakan sesutu yang opasti akan dialami oleh semua orang, setiap orang yang berumur panjang pasti akan menjadi tua. Hal ini sesuai dengan kata yang disebut siklus dan perkembangan yang dialami manusia dengan ciri yang angat jelas, seperti yang dijelaskan oleh hurlock (Bonar:2011) yaitu terjadinya perubahan fisik dan psikologis tertentu.

Perubahan fisik dan psikologis yang dialami oleh lanjut usia menentukan sampai taraf tertentu apakah lanjut usia akan melakukan penyesuaian dengan sangat baik atau dengan sangat buruk atau buruk. Menurut hurlock (Bonar:2011) ciri-ciri usia lanjut cenderung menuju membawa penyesuaian yang buruk dari pada yang baik kepada kesengsaraan dari pada kebahagiaan, hal inilah yang menyebabkan usia tua lebih ditakuti dari pada usia madya di negara amerika. 
Masa lanjut usia atau menua merupakan tahap paling akhir dari siklus kehidupan seseorang. WHO (2009) menyatakan masa lanjut usia menjadi empat golongan, yaitu usia pertengahan (middle age) 45-59 tahun, lanjut usia (elderly) 60-74 tahun, lanjut usia tua (old) 75-90 tahun dan usia sangat tua (very old) di atas 90 tahun (ananda dkk:2017).

Tahapan usia lanjut menurut Erickson 1963 dalam (parulian dkk :2016) merupakan tahap integrity versus despair, yakni individu yang sukses dalam melampaui tahap ini akan dapat beradaptasi dengan baik, menerima berbagai perubahan yang terjadi dengan tulus mampu beradaptasi dengan keterbatasan yang dimilikinya, bertambah bijak menyikapi proses kehidupan yang dialaminya, sebaliknya mereka yang gagal maka akan melewati tahap ini dengan penuh stress, rasa penolakan, marah dan putus asa terhadap kenyataan yang dialaminya.

Dukungan keluarga merupakan salah satu bentuk terapi yang diperlukan karena melalui keluarga berbagai masalah kesehatan dapat muncul dan segera diatasi. Menurut Frietman dalam (Nuri dkk : 2016) juga menjelaskan ada 4 jenis dukungan keluarga yaitu dukungan instrumental, dukungan informasional, dukungan emosional, selain dukungan keluarga, karakteristik keluarga juga mempengaruhi kemampuan individu termasuk lansia dalam mengatasi masalah kesehatan yaitu pekerjaan, pendapatan, pendidikan, tipe keluarga dan usia.

Menurut indarwati \& Tri joko (2014) upaya meningkatkan kesejahteraan social pada lansia membutuhkan rehabilitas yang disebut dengan pekerja social. Sehingga mampu memberikn manfaat langsung kepada lanjut usia. Menurut Nindy Ayu, dkk (2017) keluarga memiliki peranan yang sangatpenting dalam perawatan lansia. Jika perawatan keluarga baik maka akan baik kesehatan lansia jika keluarga buruk dalam merawa maka akan buruk kesehatan lansia.

Pada saat ini lansia kurang sekali mendapat perhatian serus ditengah keluarga terutama dalam hal pemebuhan aktfivitas kehidupan sehari-hari. Hal ini disebabkan lansia keterbatasan waktu dalam merawat diri tetapi keluarga tidak memiliki waktu untuk merawat diri.(Ratna Wulandari:2014). Kondisi kesehatan fisik secara keseluruhan mengalami kemunduran semenjak seseorang memasuki fase lansia dalam kehidupannya (Anis:2012).

\section{Pengertian Panti Jompo}

Panti Jompo merupakan upaya Pemerintah untuk mengayomi para Lansia (orang lanjut usia) yang hidup miskin dan terlantar. Undang-Undang Dasar 1945 pasal 34 telah mengamanatkan, memperhatikan "Fakir Miskin dan Anak Terlantar". Pendirian Panti Sosial didasarkan atas Undang-Undang RI no.4 Tahun 1965 tentang "Pemberian Bantuan Kehidupan bagi Orang-Orang Jompo"; Keputusan Mentri Sosial RI No.3/1/50/107/1979 tentang "Pemberian kehidupan bagi Orang-orang usia Lanjut"; Undang-Undang RI No.6 tahun 1998, tentang “Kesejahteraan Lanjut Usia.

Panti jompo menurut Kamus Besar Bahasa Indonesia, kata panti jompo diartikan sebagai tempat merawat dan menampung jompo. Panti jompo (rumah perawatan) 
merupakan sebuah tempat tinggal atau tempat penampungan bagi orang-orang yang sudah tua.

Pemilihan tempat tinggal menjadi sesuatu yang penting bagi lansia. Umunya lansia memilih hidup dengan anak-nanak mereka tetapi tidak jarang juga dia memilih hidup terpisah dari anak-anaknya. Di Indonesia salah satu tempat tinggal untuk lansia adalah panti werdah. (Cicilia :2016) .

Panti jompo merupakan unit pelaksanaan teknis yang memberikan pelayanan sosial bagi lanjut usia, yaitu berupa pemberian penampungan, jaminan hidup seperti makanan dan pakaian, pemeliharaan, kesehatan, pengisian waktu luang termasuk rekreasi, bimbingan sosial, mental serta agama, sehingga mereka dapat menikmati hari tuanya dengan diliputi ketentraman lahir batin (DEPSOS RI, 2003). Panti jompo adalah tempat tinggal yang dirancang khusus untuk orang lanjut usia, yang didalamnya disediakan semua fasilitas lengkap yang dibutuhkan orang lanjut usia (Hurlock, 1996). Panti jompo adalah tempat dimana berkumpulnya orang-orang lanjut usia yang baik secara sukarela ataupun diserahkan oleh pihak keluarga untuk diurus segala keperluannya, dimana tempat ini ada yang dikelola oleh pemerintah maupun pihak swasta (Zakiya, 2015). Adanya panti jompo ini bertujuan untuk meningkatkan kemampuan lanjut dalam rangka/ upaya mengatasi masalah kesehatannya secara mandiri dan mewujudkan derajat kesehatannya secara optimal.

\section{Karakteristik Panti Jompo}

Menurut Siti (2012), panti jompo identik dengan tempat penampungan bagi orang yang sudah tua. Kategori/ ciri-ciri orangtua yang ditampung oleh panti jompo yaitu sebagai berikut : yang memang sebatang kara dan tidak punya sanak saudara yang bisa merawatnya. Di Panti Jompo ada petugas atau sukarelawan yang bisa menemani dan merawat mereka melalui hari2 tua mereka,yang masih memiliki sanak saudara bahkan yang masih memiliki anak dan cucu tapi tidak bisa merawatnya.

Berbagai faktor para orang tua (manula) berada di panti jompo antara lain sebagai berikut : Sibuk alias tidak ada waktu (dikarenakan alasan semua orang dirumah kerja jadi tidak ada yang bisa memperhatikan kebutuhan orang yang sudah renta tersebut). Hmm... Apakah alasan ini bisa dibenarkan? Gimana waktu kita kecil sampai besar, apakah orang tua kita bisa dengan alasan sibuk jadi kagak perlu ngurus kita? Jikalaupun orangtua yang sibuk kerja and kagak bisa ngurus anaknya, apakah lantas ditaruh di Panti Asuhan? Dan Tidak mau tahu (alasannya karena tidak tauk kebutuhan dan tidak terbiasa mengurus orang tua, kalo di Panti Jompo khan sudah ada tenaga ahli yang memang pekerjaannya mengurus kebutuhan para manula) Hmm... Kalo yang ini kayaknya mengada-ada yach? Waktu orang tua kita pertama kali punya anak juga pastinya mereka kagak pernah dilatih untuk langsung bisa ngurus anak. Mereka bakal belajar seiring berjalannya waktu.

\section{Permasalahan Warga Binaan Di Panti Jompo}

Masalah yang sering dihadapi oleh lansia yang tinggal di panti jompo menurut Wreksoatmodjo (2013) adalah : 1) Lansia yang tinggal di panti umumnya kurang merasa hidup bahagia, banyak lansia yang merasa kesepian tinggal di panti padahal banyak 
lansia atau penghuni panti di sekeliling mereka, 2) Lansia yang tinggal di panti merasa sedih karena keterbatasan ekonomi, meskipun kebutuhan mereka sehari-hari terpenuhi. 3) Lansia yang tinggal di panti tercukupi kebutuhan fisik (pangan, sandang dan papan) namun mereka tetap merindukan dapat menikmati sisa hidupnya dengan tinggal bersama keluarga. 4) Lansia yang tinggal di panti, pada umumnya adalah lansia terlantar yang jauh dari anak dan cucu, akan cenderung kurang dapat memaknai hidup, mereka menjalani hidup kurang semangat, kurang optimis, dan merasa kesepian atau hampa, kurang memiliki tujuan yang jelas baik jangka pendek maupun jangka panjang, kurang bertanggung jawab terhadap diri sendiri, lingkungan dan masyarakat.5) Lansia yang tinggal di panti cenderung merasa kurang bebas menentukan pilihandalam hidupnya, mereka lebih senang tinggal di panti karena ada yang mengurusnya walaupun mereka merasa terkekang, dan mereka merasa tidak dapat bertindak sesuainilai-nilai yang diyakininya. 6) Para lansia yang tinggal di panti kurang beraktifitas, baik aktifitas fisik maupunaktifitas kognitif dan juga kurang aktif berpartisipasi dalam kegiatan masyarakat. 7) Lansia penghuni panti banyak yang 8) mengalami underweight (penurunan berat badan).Beberapa hasil penelitian di luar negeri menunjukkan bahwa lansia yang tinggal di panti lebih beresiko mengalami gangguan kognitif.

\section{Konsep diri lansia di panti jompo}

Usia lanjut dikatakan sebagai tahap akhir perkembangan pada hidup manusia termasuk biologis, psikologis dan sosial (Kusumawati dan Hartono, 2010). Lanjut usia suatu kejadian yang pasti akan dialami oleh semua orang yang dikaruniai usia panjang, terjadinya tidak bisa dihindari oleh siapa saja (Nugroho, 2008). Menurut Pujiastuti dan Budiono (2003) seseorang yang telah berumur lebih dari 60 tahun. Lansia merupakan tahap akhir dari siklus hidup manusia yang merupakan proses alamiah yang tidak dapat dihindari (Maryam, 2002). Lanjut usia terdiri dari beberapa penggelompokan umur diantaranya sebagai berikut, (1) Usia pertengahan Middle age 45-59 tahun, (2) lansia 60-74 tahun (elderly), (3) lansia tua 75-90 tahun (old), (4) usia sangat tua (very old). Lanjut usia dalam kehidupannya sehari-hari akan banyak mengalami kemunduran dan perubahanperubahan. Meliputi perubahan fisik, psikologis, perubahan mental, kognitif dan perubahan spiritual dan ekonomi. Masalah fisik yang ditemukan pada lansia adalah: Mudah jatuh dan mudah lelah. Kekacauan mental akut, nyeri dada, berdebardebar, sesak nafas, pembengkakan, sulit tidur, pusing, dan perubahanperubahan pada mental atau psikososial sehingga akan mempengarui konsep diri ( Nugroho, 2008).

Konsep diri merupakan gambaran tentang diri kita, tentang apa yang kita pikirkan dan kita rasakan dan merupakan kumpulan dari berbagai pengalaman dan utamanya dalam hubungan dengan orang lain interactional with other) (Tasmara, 2006). Penurunan konsep diri akan mempengarui pola pemikiran lanjut usia terhadap perilakunya. Perubahan konsep diri pada lanjut usia terutama disebabkan oleh kesadaran subyektif yang terjadi yang sejalan dengan bertambahnya usia. Apabila lanjut usia menyadari perubahan adanya perubahan fisik dan psikis yang terjadi pada diri mereka maka akan berfikir dan bertingkah laku yang seharusnya dilakukan oleh lanjut usia. 
Lanjut usia akan banyak mengalami perubahan fisik kemampuan dan fungsi tubuh yang akan mengkibatkan tidak stabilnya konsep diri (Nugroho, 2008).

Konsep diri lansia dipengarui oleh pengalaman-pengalaman sepanjang hidup lansia dan berkembang melalui proses yang sangat kompleks yang melibatkan banyak komponen. Komponen konsep diri, Gambaran diri atau citra diri, ideal diri, harga diri, identitas diri, penampilan dan peran (Potter \& perry, 2002) Gambaran diri atau citra diri (body image) mencakup sikap individu terhadap tubuhnya sendiri, termasuk penampilan fisik, struktur dan fungsinya yang dipengaruhi oleh pertumbuhan.

\section{KESIMPULAN}

Berdasarkan penjelasan diatas dapat diambil kesimpulan bahwa konsep diri lansia yang hidup dipanti jompo ada menurun atau merosot yakni merasa tua, tidak berguna, tidak ada yang mau menerima dan merawatnya.dan adajuga sebagian yang memiliki konsep diri bagus yaitu merasa banyak teman dan tidak jenuh ketika seperti keadaan di rumah. Semua pihak setidaknya dapat memahami bahwa banyak penurunan yang akan dialami oleh lansia, dan sebagai anak kita harus paham bahwa orantua butuh kita.

\section{REFERENCES}

Ananda Ruth Naftali, dkk. (2017). Kesehatan spiritual dan kesiapan lansia dalam menghadapi kematian. Vol 25, No 2, Hal 124-135

Anis Ika Nur Rahman, dkk. (2012). Kualitas hidup lanjut usia. Volume 3 nomor 2. Halaman 126.

Bonar. (2011). Emotional Intelegence dan Psychological well-being pada mansia lanjut Anggota lanjut Berbasis keagamaan di jakarta . volume 13 nomor 12

Cicilia Pali. (2016). Gambaran kebahagiaan lansia yang tinggal di panti werda. Volume 4 nomor 1.

DEPSOS RI. (2003). Rencana Aksi Nasional untuk Kesejahteraan Lanjut Usia. Jakarta: Departemen Sosial Republik Indonesia.

Hurlock. (1996). Psikologi Perkembangan Suatu Pendekatan Sepanjang Rentang Kehidupan. Jakarta: Erlangga.

H. Jalali. (2008). Psikologi pendidikan. Jakarta: Bumi Aksara

I Nyoman Surna \& Olga. (2014). Psikologi pendidikan. Jakarta: Erlangga

Indarwati \& tri joko raharjo. (2014). Peranan pekerja social dalam meningkatkan Kesejahteraan. Lansia.Volume 3 nomor 3. Halaman 24.

Nuri Nazari, dkk. (2016). Family support and characteristics of the caring family on the erderly nutrition.Volume 4 nomor 2.

Nindi Ayu Prabasari. (2017). Pengalaman keluarga dalam merawat lansia di rumah Volume 5 nomor 1 Halaman 58. 
Nugroho, Wahjudi. (2008). Keperawatan Gerontik \& Geriatrik. Ediisi 3. Jakarta : Kedokteran eeg.

Parulian Gultom, dkk. (2016). Hubungan aktivitas spiritual dengan tingkat depresi pada lansia di balai lanjut usia senja cerah kota manado.

Ratna Wulandari. (2014). Gambaran tingkat kemandirian lansia dalam pemenuhan ADL. Volume 1 nomor 2. Halaman 145.

Ratna Dwi. (2014). Identifikasi factor-faktro yang mempengaruhi konsep diri siswa. Jakarta: UNY.

Rahayu, Hiswani, \& Ramelah. (2003). Gambaran Lanjut Usia Yang Tinggal di Panti. UPTD: Abdi.

Siti Aisyah and Achmad Hidir. (2012). Kehidupan Sosial Lanjut Usia Di Panti Sosial Tresna Werdha Khusnul Khotimah Pekanbaru. Skripsi. Jurusan Sosiologi Fakultas Ilmu Sosial dan Ilmu Politik Universitas Riau.

Stanley, M. \& Beare, P.G. (2007). Buku Ajar Keperawatan Gerontik. Edisi 2. Jakarta: Eeg.

Wreksoatmodjo. (2013). Perbedaan Karakteristik Lanjut Usia yang Tinggal di Keluarga dengan yang Tinggal di Panti. Jakarta: FKM UI

Zakiya Hidayah. (2015). Laporan Panti Wreda. (online) http://zakiyahidayah. blogspot.com/2015/11/laporan-panti-wreda.html Diakses pada Minggu, 18 Desember 2018 pukul 20.00 WIB 